
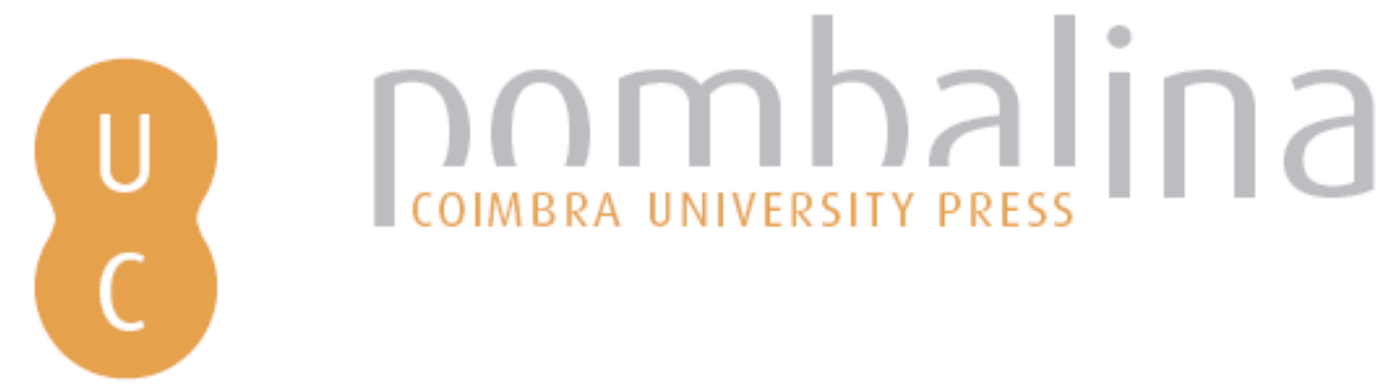

\title{
Um percurso político: José Bruno Tavares Carreiro (1880-1957): de abnegado regenerador a autonomista pragmático
}
Autor(es):
Cordeiro, Carlos
Publicado por: Imprensa da Universidade de Coimbra
URL
persistente:
URI:http://hdl.handle.net/10316.2/31584
DOI:
DOI:http://dx.doi.org/10.14195/978-989-26-0199-1_7
Accessed : $\quad$ 26-Apr-2023 11:29:55

A navegação consulta e descarregamento dos títulos inseridos nas Bibliotecas Digitais UC Digitalis, UC Pombalina e UC Impactum, pressupõem a aceitação plena e sem reservas dos Termos e Condições de Uso destas Bibliotecas Digitais, disponíveis em https://digitalis.uc.pt/pt-pt/termos.

Conforme exposto nos referidos Termos e Condições de Uso, o descarregamento de títulos de acesso restrito requer uma licença válida de autorização devendo o utilizador aceder ao(s) documento(s) a partir de um endereço de IP da instituição detentora da supramencionada licença.

Ao utilizador é apenas permitido o descarregamento para uso pessoal, pelo que o emprego do(s) título(s) descarregado(s) para outro fim, designadamente comercial, carece de autorização do respetivo autor ou editor da obra.

Na medida em que todas as obras da UC Digitalis se encontram protegidas pelo Código do Direito de Autor e Direitos Conexos e demais legislação aplicável, toda a cópia, parcial ou total, deste documento, nos casos em que é legalmente admitida, deverá conter ou fazer-se acompanhar por este aviso.

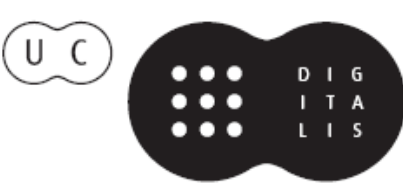


Maria Manuela Tavares Ribeiro

Coordenação

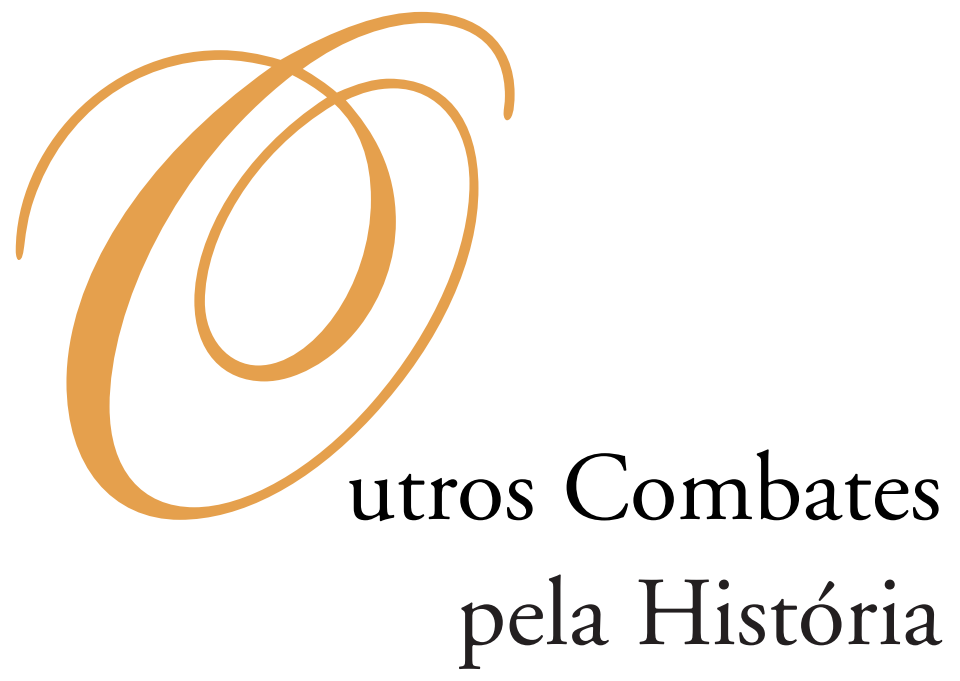




\section{COORDENAÇĀO EDITORIAL}

Imprensa da Universidade de Coimbra

Email: imprensauc@ci.uc.pt

URL: http://www.uc.pt/imprensa_uc

Vendas online: http://livrariadaimprensa.com

\section{CONCEPÇÃO GRÁFICA}

António Barros

\section{ORgANIZAÇĀO DOS TEXTOS}

Isabel Maria Luciano

Marlene Taveira

PRÉ-IMPRESSÃO

António Resende

Imprensa da Universidade de Coimbra

EXECUÇÃO GRÁFICA

SerSilito • Maia

ISBN

978-989-26-0041-3

DEPósito LEGAL

OBRA PUBLICADA COM O APOIO DE:

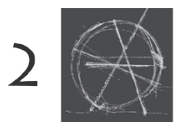

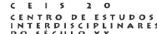

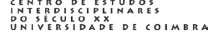

FCT Fundação para a Ciência e a Tecnologia

MINISTÉRIO DA CIÊNCIA, TECNOLOGIA E ENSINO SUPERIOR Portugal

Programa Operacional Ciência, Tecnologia, INOVAÇĀo DO QUADRo COMUNITÁRIO DE APOIO III

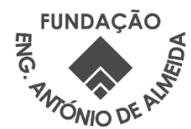

C JULHO 2010, IMPRENSA DA UNIVERSIDADE DE COIMBRA 
Maria Manuela Tavares Ribeiro

Coordenação

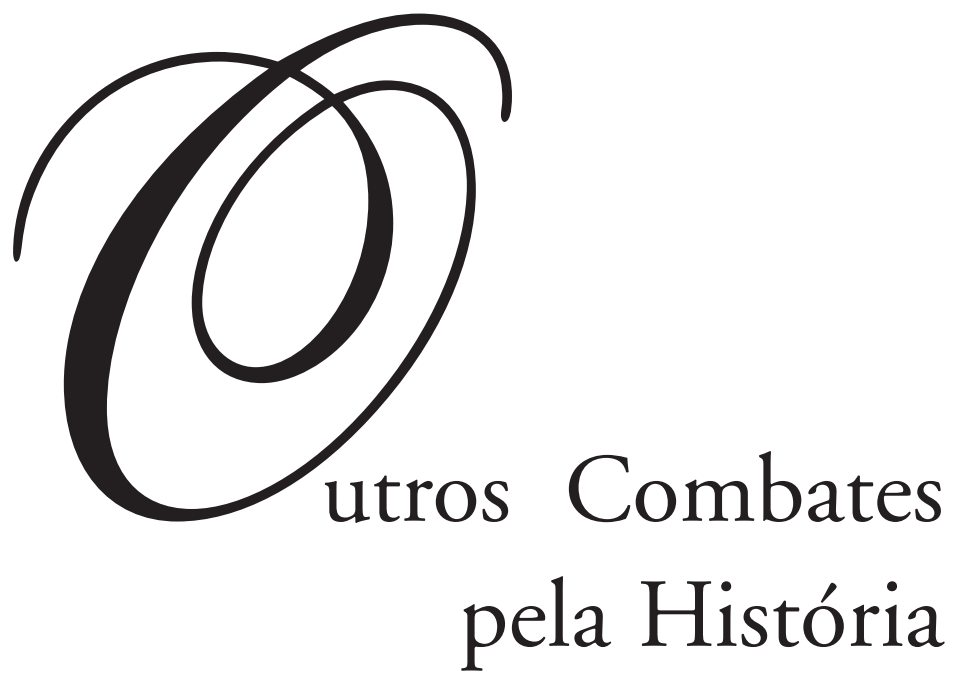

- colmbra 2010 
História e Política 


\section{Carlos Cordeiro}

\section{UM PERCURSO POLÍTICO: \\ José Bruno TaVares Carreiro (1880-1957). DE ABNEGADO REGENERADOR A AUTONOMISTA PRAGMÁTICO}

A História tem assistido, nos últimos tempos, à renovação dos estudos biográficos. Após décadas de uma historiografia preocupada, sobretudo, com as análises estruturais sobre a economia, os movimentos sociais, a evolução das mentalidades, em que o indivíduo parecia ter sido relegado para o limbo da História, regressa o estudo biográfico, não enquanto exercício panegírico, mas na abordagem científica do papel do biografado no ou nos contextos históricos que é preciso compreender.

Não será, propriamente, um estudo biográfico que nos propomos apresentar sobre tão importante personalidade da cultura, da política e do jornalismo açoriano. O nosso propósito limita-se a, com base na bibliografia e documentação que pudemos consultar, esboçar a intervenção política de José Bruno Tavares Carreiro em contextos históricos tão diversos como os da Monarquia Constitucional, a I República, a Ditadura Militar e (menos significativamente) o Estado Novo. Não serão mais do que ténues traços de um percurso que apresentamos com hiatos bem notórios. E, certamente, isto fica a dever-se não a uma menos relevante participação na vida comunitária nesses períodos, mas ao facto de não termos acedido a fontes documentais ou outras que, de algum modo, pudessem ilustrar melhor as suas preocupaçôes, os seus propósitos e a indagação das soluçôes que considerava mais justas e adequadas ao desenvolvimento e bem-estar da sociedade açoriana. Estamos, porém, certos de que a sua influência não deixaria de se fazer notar nos círculos políticos e intelectuais com que mantinha contactos.

E neste percurso não podemos deixar de ter em conta que a vida pública de José Bruno se insere em tempos de grandes mudanças aos mais diversos níveis. Desde logo, a nível internacional, a ocorrência das duas guerras mundiais, com todos os flagelos que delas resultaram. Em termos nacionais, é bem agitado o percurso político: a crise da Monarquia Constitucional, o regicídio, a implantação da República, a participação de Portugal na Grande Guerra, a Ditadura Militar, o autoritarismo estadonovista. Foi, pois, nesse mundo de profundas alterações que se movimentou José Bruno Carreiro, que, além do mais, foi um importante homem de cultura ${ }^{1}$.

\footnotetext{
${ }^{1}$ A sua obra Antero de Quental: subsidios para a sua biografia (2 volumes), Lisboa, ed. do Instituto Cultural de Ponta Delgada, 1948 continua a ser de consulta obrigatória. Em 1949 publicaria Hintze Ribeiro,
} 
Falta-nos, ainda, uma biografia de José Bruno Carreiro, e é já bem tempo de se ir pensando nessa hipótese, por exemplo, a nível de provas académicas. Não há dúvidas de que a conferência do Dr. João Bernardo Rodrigues, em 1980, aquando do centenário do nascimento de José Bruno, publicada em separata pela Insulana ${ }^{2}$, é merecedora de vivo elogio pela investigação que comporta e pela compreensão do relevo de José Bruno, não só nos âmbitos do jornalismo e da política, mas também nas áreas da cultura e da administração pública. Mas trata-se de um texto que resulta de uma conferência, com as compreensíveis limitaçōes que isto implica. Estou convencido de que a figura e a obra de José Bruno Tavares Carreiro serão ainda objecto de um trabalho científico de qualidade, ainda que se compreenda as dificuldades de o encetar, visto que implicará uma abordagem de tipo interdisciplinar, dadas as actividades em que se envolveu e campos de interesse que cultivou.

Nascido em 1880, em Coimbra, a infância de José Bruno Carreiro foi passada em Ponta Delgada, tendo, depois, frequentado o liceu no continente. A primeira matrícula de José Bruno na Universidade de Coimbra verifica-se no ano lectivo de 1899/1900. Frequentaria, até 1904, a Faculdade de Direito. Ai conviveu, certamente, com colegas que, num lado ou no outro das barricadas políticas e ideológicas, viriam a destacar-se na vida política e cultural do País $^{3}$. Colegas seus chegaram a ministros, quer no período da I República ${ }^{4}$, quer no do Estado Novo ${ }^{5}$. Outros foram diplomatas ${ }^{6}$, governadores civis, presidentes de câmara, professores universitários, juízes conselheiros. Conviveu com republicanos, com monárquicos, com republicanos que se tornaram monárquicos ${ }^{7}$ e com monárquicos que se tornaram republicanos.

Foi, por exemplo, colega e amigo de Alberto Costa, o famoso Pad-Zé a quem, aliás, dedica uma sentida homenagem nas colunas do seu jornal, por alturas do suicídio do autor de $O$ Livro do Doutor Assis. Neste artigo, refere-se à vida boémia de Pad-Zé e relembra episódios que, de algum modo, apontam no sentido de José Bruno também não ter sido alheio à boémia:

sep. da «Insulana», V (3-4), Instituto Cultural de Ponta Delgada. Em 1955 viria a público a Vida de Teófilo Braga. Resumo Cronológico, Coimbra, Coimbra Editora, 1955 e Cartas de Amor à Viscondessa da Luz, de Garrett (coord e anot.), Lisboa, ed. da Empresa Nacional de Publicidade, s. d. (1955). Publicou ainda O Drama do Capitão Dreyfus, ed. Educação Nacional, Porto, s. d. (1951), A Aliança Inglesa: o grande triunfo da diplomacia portuguesa na confirmação da aliança pela declaração secreta de 14 de Outubro de 1899, Coimbra, Arquipélago, 1960, além de ter colaboração dispersa por jornais e revistas regionais e nacionais.

2 João Bernardo de Oliveira Rodrigues, "Dr. José Bruno Carreiro», in Insulana. Órgão do Instituto Cultural de Ponta Delgada, vols. XXXVI-XXXVII (1981-1982), Ponta Delgada, ICPD, pp. 78-110.

3 Jaime Cortesão, por exemplo, colega de José Bruno no 1. ${ }^{\circ}$ ano, no ano lectivo de 1899-1900. Foi também colega de José d'Arruella, do dramaturgo Alfredo Cortês, do conhecido professor universitário Beleza dos Santos. Cf. Anuário da Universidade de Coimbra. Ano lectivo de 1899-1900, Coimbra, Imprensa da Universidade, 1900, pp. 55-58.

${ }^{4} \mathrm{O}$ caso de João de Barros, ministro dos Negócios Estrangeiros em 1924-25.

5 José Caeiro da Matta, que foi ministro dos Negócios Estrangeiros e ministro da Educação Nacional, nos anos 30 e 40 .

${ }^{6} \mathrm{O}$ caso de Rui Ulrich.

7 Alfredo Pimenta será um deles. 
«Num instante e num trabalho prodigioso de imaginação, todas as hipóteses ficavam previstas, todos os cálculos feitos e todas as dificuldades varridas, quer pensasse na implantação da República, quer se tratasse da organização do programa de uma complicada noite, a começar com bocks no Lusitano e a acabar com uma ceia de madrugada, em Tentúgal, onde muitas vezes o sol nos surpreendeu abancados a uma mesa junto da lareira, atacando uma travessa de peixe frito ou devorando nacos de vitela assada, - enquanto o Pad-Zé, muito sério, de pé, com o copo na mão, ia recitando uma célebre ode» 8 .

Esta camaradagem está, aliás, bem expressa no facto de José Bruno Carreiro ter incluído, com grande destaque, a personagem do Pad-Zé (desempenhada pelo próprio), em Uma Véspera de Feriado. Peça de costumes de Coimbra? ${ }^{9}$.

Vivia-se, na Universidade, um ambiente de certa forma agitado, herdeiro das fortes movimentaçôes estudantis na sequência do Ultimato de 1890, mas também reflexo da designada crise do fim do século.

Com efeito, as ideias de decadência e da consequente urgência de regeneração dos diversos sectores da vida nacional, especialmente o político, marcavam, sem dúvida, o discurso cultural dessa transição do século XIX para o XX, a que, naturalmente, a Universidade não ficava alheia ${ }^{10}$. Aliás, a oração de sapiência proferida por Bernardino Machado a abrir o ano lectivo de 1904-1905 transporta a ideia de crise para dentro da própria Universidade:

«Em tudo, eu identifico, no meu pensamento, e no meu coração, a imagem da escola com a imagem da pátria, em tudo, nas minhas tristezas pelos seus revezes e decadência, como na minha inextinguível confiança no seu ressurgimento» ${ }^{11}$.

Havia, pois, a necessidade de uma profunda reestruturação do ensino, e a transformação da Universidade em lugar de liberdade e criação: «uma universidade — dizia - deve ser uma escola de tudo, mas sobretudo de liberdade. Nem o professor é um pontífice, nem o discípulo um catecúmeno» ${ }^{12}$. É, pois, neste ambiente de efervescência cultural e política que José Bruno se forma em Direito.

Duas décadas passadas, Joaquim Manso, director do Diário de Lisboa, que integrara a «Missão Intelectual» (1924), caracteriza José Bruno como um estudante dado à boémia:

8 José Bruno, «Alberto Costa 'Pad-Zé’. À memória de um amigo», in O Distrito, Ponta Delgada, 1908, Novembro, 18.

${ }^{9}$ José Bruno, Uma Véspera de Feriado. Peça de costumes de Coimbra, 3. a edição, Coimbra, Coimbra Editora, Limitada, 1929 (1.a edição - Coimbra, 1904).

10 Sobre o assunto, veja-se, por exemplo, a síntese de José Esteves Pereira, «A tensão entre progresso e tradição", in António Reis (dir.), Portugal Contemporâneo, Lisboa, Publicações Alfa, S. A., vol. II, 1990.

${ }^{11}$ Bernardino Machado, A Universidade e a Nação. Oração inaugural do ano lectivo 1904-1905, recitada na sala grande dos actos da Universidade de Coimbra no dia 16 de Outubro de 1904, Coimbra, Imprensa da Universidade, 1904, p. 19.

12 Ibidem, p. 5. 
«Primeiramente o José Bruno foi para mim o eco dum nome, o vago fantasma dum estudante de Coimbra cuja mocidade não se consumia unicamente no estudo e na veneração dos mestres, pois que para além dos severos textos civilistas tinha a sua lenda de poeta, de boémio, de insubmisso, com a elegância natural de quem já sabia que a palavra e o gesto são a melhor paisagem para o espírito. Acabada a formatura, da cidade de Minerva transitou você para a de Ulisses e da capa e batina, oleografia romântica do Choupal e arrepiada água-forte da Via Latina, passou para a estúrdia lisboeta, cuja sala dos capelos era o «Tavares», onde você mostrava à roda dos seus íntimos que tinha talento para ser milionário e um santo pai em Ponta Delgada, que, com as suas mesadas pontuais, contribuía para elevar o preço do Pommery» [...].

Creio [...] que uma noite alguém me perguntou: viste o José Bruno? Eu, que nunca gozara a graça da sua presença, sentindo que ele existia mais como um tema lírico, uma razão sentimental de efémeras ceias de mancebos nostálgicos, respondi: o José Bruno está neste momento a ser tocado à guitarra num gabinete do Tavares!» ${ }^{13}$

Passados vinte e cinco anos, o olhar retrospectivo de José Bruno Carreiro sobre o ambiente universitário "do seu tempo" é já algo crítico. Considerava então a geração a que pertencera, a famosa "geração do centenário da sebenta» ${ }^{14}$, como «iconoclasta» e "céptica»: "tudo era ainda, como cantou Afonso Lopes Vieira, o romance, a troça, a banza e a cantiga» ${ }^{15}$. Tratava-se, na sua opinião, de uma geração marcada por "uma atmosfera de negativismo demolidor», contrariamente ao que acontecia um quarto de século passado:

«Parece-me que a geração de hoje possui geralmente das coisas do mundo e da vida uma noção mais grave, mais nobre, mais alta do que nós no nosso tempo de estudantes» ${ }^{16}$.

Nesse intervalo assistira-se ao fim da Monarquia, à implantação da República, à sua decadência e queda e ao golpe do 28 de Maio de 1926, para além, naturalmente, da Grande Guerra com todo o seu cortejo de desgraças. No fundo, os jovens estudantes, desde cedo, se haviam confrontado com a «derrocada que convulsiona as sociedades» e debatido com a anarquia num mundo saído da Guerra. Tivera, pois, a nova geração que fazer escolhas, até por instinto de conservação — salvando o país do "suicídio nacional» 17 .

O que nos sugere a leitura do prefácio à $3 .^{a}$ edição de Uma Véspera de Feriado... é uma certa expectativa na possibilidade de «redenção nacional», que a sua geração de Coimbra não soubera acalentar, antes a desbaratara num mundo de fantasia.

13 Carta de Joaquim Manso a José Bruno Carreiro [Lisboa?], [1924]. SDUA, Fundo Carreiro da Costa.

${ }^{14}$ V. a descrição do "centenário da sebenta", de 1899, em Trindade Coelho, In Illo Tempore. Estudantes, lentes e futricas, 8. ${ }^{\mathrm{a}}$ ed. Lisboa, Portugália, 1969.

15 José Bruno, Uma Véspera..., p. XV.

16 Ibidem, p. XIV.

17 Ibidem, p. XIV. 
Relativamente à formação académica, não é menos crítico o filtro da memória:

«Muitos fomos [...] os que um dia partimos do Mondego sem qualquer vestígio da ciência que durante cinco anos nos fora laboriosamente ministrada» 18 .

Findo o curso, não seguiria os passos dos colegas que optaram pela contestação republicana ao poder instituído. Saiu monárquico regenerador, num contexto político-partidário marcado pelo divisionismo e a desagregação dos partidos do designado «rotativismo monárquico». Uma conjuntura em que eram patentes os sintomas de decadência das instituições monárquicas. João Franco governava, primeiro apoiado na «concentração liberal», depois, em ditadura.

José Bruno Carreiro assumiu, em Ponta Delgada, a propriedade e a direcção de um novo jornal: $O$ Distrito, com primeiro número datado de 5 de Julho de 1906, para apoiar, sem reservas, o Partido Regenerador. O jornal é nitidamente partidário: semanário regenerador ${ }^{19}$, como vinha bem expresso em subtítulo. Teve como primeira missão a propaganda eleitoral regeneradora numa oposição difícil à "concentração liberal», que incluía franquistas e progressistas, localmente bem dirigidos por José Maria Raposo de Amaral, talvez o mais prestigiado líder político micaelense da época. O jornal ataca com profunda virulência os seus opositores políticos, tendo mesmo sido levantados três processos judiciais ao seu director. Alguns artigos atingiam o ataque pessoal, sobretudo nas referências ao presidente do Governo e ao chefe dos progressistas locais, Raposo do Amaral ${ }^{20}$. João Franco chega, por exemplo, a ser tratado como "réu confesso da desonra pessoal e política» ${ }^{21}$, de "ambicioso medíocre», de «aventureiro desqualificado política e moralmente» ou de «epiléptico ${ }^{22}$ atacado de monomania presidencial» 23 , questionando-se: «estamos em face de um cínico ou de um doido?» 24

O seu jornal, e certamente pela sua pena, lançou também críticas acesas à intervenção da Igreja nos assuntos da política, entrando numa acesa polémica com o jornal São Miguel, do Partido Nacionalista, e desafiando o bispo da diocese a esclarecer os fiéis sobre a separação entre assuntos políticos e questôes religiosas ${ }^{25}$.

18 Ibidem, p. XVI.

19 O Distrito. Semanário Regenerador, n. ${ }^{\circ}$ 1, Ponta Delgada, 1906, Julho, 5.

${ }^{20}$ José Maria Raposo de Amaral é considerado, por exemplo, «um chefe político sem ideias, sem convicções, sem princípios e sem brio, excelente galopim eleitoral e apreciável meneur de eleiçōes». O Distrito, Ponta Delgada, 1907, Junho, 20.

${ }^{21}$ O Distrito, Ponta Delgada, 1907, Junho, 6.

$22 \mathrm{O}$ jornal lisboeta, de tendência republicana, $O$ Mundo, de 18 de Junho de 1907, publicava um panfleto do médico Artur Barbosa Leitão, em que João Franco era apresentado como um louco epiléptico, irresponsável e perigoso. Cf. José Miguel Sardica, A Dupla Face do Franquismo na Crise da Monarquia Portuguesa, Lisboa, Ediçốes Cosmos, 1994, p. 62.

23 O Distrito, Ponta Delgada, 1907, Junho, 6.

${ }^{24}$ Ibidem, Idem.

25 Cf. O Distrito, Ponta Delgada, 1908, Maio, 21 e 1908, Junho, 4. 
Num dos artigos que deu azo a processo por abuso de liberdade de imprensa, José Bruno, referindo-se ao telegrama que Franco dirigira ao Governador Civil dando conta do êxito da sua viagem em missão política ao Porto, afirma que tal só fora possível por ele ter uma "pinguinha de bebida", encontrar-se "carregadinho» ${ }^{26}$. A lei de 11 de Abril de 1907 , a chamada «lei das rolhas», que visava tornar a imprensa mais «ordeira», não teve eficácia neste caso como, aliás, ocorreu em inúmeros julgamentos sobre o abuso da liberdade de imprensa, com base na lei de 11 de Abril de $1907^{27}$.

Aliás, o julgamento transforma-se num libelo virulentíssimo contra o governo de João Franco, num «discurso» de José Bruno ao Tribunal, afirmando nada retirar do que dissera. Segundo a reportagem do jornal, José Bruno dirigira-se ao Tribunal nos seguintes termos:

«Escreveu-o [o artigo em questão], não num momento de exaltação, mas num momento de bom humor e de gargalhada, provocada pelo telegrama do presidente do conselho, - o que não impede que o discuta agora muitíssimo a sério.

É certo que poderia chegar ali e dizer:

- Peço desculpa, enganei-me, não foi por mal, já aqui não está quem falou. Poderia mesmo desinteressar-se do telegrama, como costuma fazer o sr. João Franco, sempre que vê as coisas mal paradas!... O exemplo vir-lhe-ia da presidência do conselho de ministros.

Embora, porém, o sr. Franco paire nas estonteadoras alturas dessa presidência e ele, orador, vegete cá muito em baixo, na pedregosíssima e mal calçadíssima rua do Gaspar desta cidade - quer ter o orgulho de manter tudo quanto disse, com razão ou sem ela, mas com sinceridade, com lógica e sem a intenção criminosa que lhe atribui o ministério público.

Portanto, nem ele nem o seu advogado apelarão para o coração dos juízes, porque ele nada tem que ver para ali» ${ }^{28}$.

Mas, além desta assunção, com orgulho, de tudo o que escrevera no referido artigo, esta longa intervenção de José Bruno Carreiro ia mais longe nas acusações a João Franco e na defesa dos ideais de liberdade.

26 Idem, Ponta Delgada, 1907, Maio, 9.

27 «O famoso poder judicial, por que João Franco tanto esperava para limitar o arbítrio dos governos, começou logo a exercer essa função, mas contra o próprio Franco. Nos julgamentos por querelas de imprensa, eram raras as condenações. Os jornalistas podiam apelar ao regicídio, ao assalto às Necessidades, que os juízes, exibindo a mais despudorada benevolência, absolviam a torto e a direito". Rui Ramos, $A$ Segunda Fundação (1890-1926), v vol. da História De PORTUGAL, dirigida por José Mattoso, Lisboa, Círculo de Leitores, 1994, p. 285. Em 20 de Junho, uma nova lei de imprensa «agravava o conteúdo da de 11 de Abril, proibindo os escritos, desenhos ou impressos 'atentatórios da ordem pública' e dando plenos poderes aos governadores civis dos distritos para suspenderem periódicos e decidirem sobre novas publicações, sem qualquer recurso para autoridades superiores». A. H. de Oliveira Marques (coord.), Portugal da Monarquia para a República, vol. XI da NOva História de PORTUGAL, dirigida por Joel Serrão e A. H. de Oliveira Marques, Lisboa, Presença, 1991, p. 691.

28 O Distrito, Ponta Delgada, 1907, Julho, 25. 
«Apertado, pois, no dilema da estupidez córnea e da má fé cínica, resolveu fazer apenas uma crítica humorística, de preferência a apresentar o chefe do governo como uma criatura que mente, esquecendo-se do respeito que deve a si próprio e ao lugar que ocupa e expedindo oficialmente telegramas que são um acervo de falsidades e mentiras. $[\ldots]$

É mentira [...] que tenha sido completo o êxito político dessa viagem, porque ela só serviu para rebaixar e desprestigiar o princípio da autoridade na pessoa do primeiro representante das instituições, depois do Rei!... [...]

Em nome do liberalismo e da liberdade se comete tudo na época em que vivemos - em nome da liberdade se prende, se acutila e se mata, se faz a lei da imprensa, se encerra o parlamento, se viola a Carta, se originam processos da natureza deste - e deve ser até em nome da liberdade que se redigem telegramas da espécie daquele que o sr. João Franco para aqui expediu - liberdade de mistificação! [...]

Não há palavra maior nem mais sagrada do que essa. Mas, precisamente por isso, ninguém tem o direito de a prostituir, porque nessa prostituição está mais do que o suficiente para erguer num grande gesto de desprezo e num grande brado de indignação todas as consciências verdadeiramente liberais» ${ }^{29}$.

A sentença é realmente significativa da discordância de muitos juízes relativamente à lei da imprensa franquista. Num dos considerandos diz-se:

«Considerando que o povo português - cuja maioria, infelizmente, vive em atraso lamentável de instrução, é de há muito responsável pela sua política, mas não pode compreender nitidamente a linguagem correcta das academias - e que, por este motivo, quem a ele se dirige e deseja, por interesse nacional, partidário e próprio ser compreendido, tem de empregar linguagem comum e acessível a todos» 30 .

Assim e com outros considerandos do mesmo teor, o réu foi ilibado, recebendo as felicitações de uma multidão que assistira ao julgamento e o esperava à saída para o acompanhar, no meio de aplausos, até à redacção. A fachada do edifício sede do jornal foi iluminada a balóes venezianos, mantendo-se a redacção aberta até tarde para que José Bruno pudesse receber as felicitaçōes de «numerosos amigos e correligionários». Houve mesmo direito a banda de música.

Aquando do regicídio, José Bruno encontrava-se em viagem pelo estrangeiro. No seu regresso à direcção do jornal, em Abril de 1908, faria referência ao regicídio de uma maneira, de algum modo, ambígua. Desde logo, o artigo não começa propriamente pela questão do regicídio, mas por atacar a política seguida por João Franco e pelo Partido Progressista de S. Miguel. Só depois afirma o seu dever de «dirigir duas palavras de merecida homenagem à memória do rei», que caíra «varado pelas balas no cumprimento que se lhe afigurava, por fatalidade e no mais terrível dos erros, o cumprimento de um dever cívico e patriótico» ${ }^{31}$. Mas, o que mais sobressai nesse seu

\footnotetext{
${ }^{29}$ Ibidem.

${ }^{30}$ Ibidem.

31 O Distrito, Ponta Delgada, 1908, Abril, 23.
} 
artigo é o facto de homenagear, simultaneamente, o rei e os seus assassinos, considerando que estes «encarnaram a cólera popular, simbolizando a tempestade de indignação que em todo o país tinham determinado os decretos da ditadura», acrescentando:

«Não podemos deixar de nos descobrir perante as suas memórias, porque são as memórias de homens que tiveram a sublime e sempre nobre coragem de morrer por uma Ideia e de sacrificar a vida por aquilo que, também eles, também por fatalidade e no mais terrível dos erros, se lhes afigurou o cumprimento de um dever cívico e patriótico» 32 .

No entanto, deixava bem claro que a homenagem ao rei a fazia como homem e político monárquico; aos regicidas, somente como homem. Mesmo assim, era claro na reprovação da "extraordinária e inacreditável apoteose» feita aos seus cadáveres. No fundo, José Bruno interpretava o dramático acontecimento como resultado, não só da política de João Franco, um «ditador cuja vaidade corria paredes meias com a mais palpável das mediocridades», mas também do apoio que o monarca lhe concedera para governar em ditadora 33 .

A leitura do jornal $O$ Distrito é bem elucidativa sobre o agitado clima político e as profundas rivalidades partidárias que, de algum modo, preparavam já o caminho para a queda das instituiçôes monárquicas e a instauração da República. No semanário, ao longo de cerca de dois anos e meio, José Bruno Carreiro foi, sem dúvida, o jornalista empenhado num «jornal de combate», como ele próprio o designava, em defesa do seu Partido e no confronto acérrimo e, como vimos, violento com seus adversários, numa linha de conduta que, ao encerrar a publicação do jornal, o seu director afirma ter sido a de que "os actos públicos dos homens públicos são do domínio da imprensa» 34 .

Um aspecto, nesta sua incursão pela imprensa político-partidária, julgamos ser de destacar: a coragem de enfrentar, de modo por vezes bastante mordaz, áspero mesmo, as principais autoridades distritais e concelhias e as lideranças políticas locais. É evidente que o estilo da imprensa "de combate» da época era pautado por essa virulência de discurso. Mas não é menos certo que José Bruno não se encontrava a fazer jornalismo numa grande urbe ou numa comunidade que lhe fosse alheia, mas numa pequena cidade onde familiar e socialmente se encontrava bem integrado e era restrito o círculo dos detentores do poder. Seria, pois, natural a animosidade com que era lido o seu jornal pelos opositores políticos, o que, aliás, se pode confirmar pelo facto de lhe terem sido levantados três processos por abuso de liberdade de imprensa e pelos protestos públicos de alguns dos mais altos responsáveis políticos de então ${ }^{35}$.

32 Ibidem.

33 José Miguel Sardica destaca, a este propósito: «Para a opiniāo pública portuguesa, quer entre monárquicos quer entre republicanos, o regicídio foi interpretado como o corolário lógico das arbitrariedades e repressóes da ditadura e, a um nível geral, de um sentimento crescentemente avolumado de ineficácia do regime». José Miguel Sardica, ob. cit., p. 67.

34 O Distrito, Ponta Delgada, 1908, Dezembro, 31. O jornal iniciou uma segunda série a partir de 14 de Julho de 1910, mantendo-se "semanário regenerador», sob a direcção de Manuel da Câmara. O último número é datado de 6 de Outubro de 1910, mas só a capa.

35 Ibidem. 
Mas o certo também é que a imprensa "da situação" utilizava as mesmas armas, que arremessava com idêntico vigor.

Após concurso público, José Bruno Carreiro é investido, logo no mês a seguir à implantação da República, no cargo de secretário-geral do Governo Civil de Ponta Delgada. Tratava-se de um cargo de extrema responsabilidade na administração pública distrital, ainda que não fosse um cargo de confiança política, mas da carreira do funcionalismo público. O certo, porém, é que nas circunstâncias em que o governador civil ou o seu substituto, por qualquer motivo, não estivessem em funções era o secretário-geral que, interinamente, desempenhava o mais alto cargo da administração distrital, o que se verificou inúmeras vezes, quer no período da I República, quer durante a Ditadura Militar e o Estado Novo.

Esta nomeação receberia apoio, por exemplo, dos jornais Diário dos Açores, e de A Folha, este dirigido por Alice Moderno, ambos já defensores do novo regime. Segundo o Diário dos Açores, a notícia fora «recebida com geral agrado, pelas numerosas simpatias» de que desfrutava o nomeado na sociedade micaelense, louvando o governo por, "com justiça e acerto", ter escolhido José Bruno, "um dos que mais cabalmente poderiam exercer aquele cargo» 36 . Entretanto, decorriam os preparativos para uma recepção condigna aquando do seu regresso a Ponta Delgada. Alice Moderno - que já dedicara trechos poéticos a Suas Majestades, aquando da "visita régia», e também à implantação da República ${ }^{37}$ — escreveu a letra de um hino, composto pelo músico da banda regimental, Santos Coutinho. O jornal informava ainda que a banda "União Fraternal", de Ponta Delgada, se encontrava a ensaiar o hino para o interpretar no dia de regresso de José Bruno a S. Miguel, como "prova de simpatia e regozijo pela nomeação de secretário-geral do governo civil» ${ }^{38}$.

Com efeito, a 24 de Novembro, a «União Fraternal», acompanhada de uma marcha aux flambeaux, dirigiu-se a casa do Dr. José Bruno Carreiro, saudando-o com o hino. Segundo o Diário dos Açores, uma parte da rua encontrava-se apinhada de gente (seriam mais de mil pessoas), enquanto subiam ao ar alguns foguetes e se lançavam diversos vivas, «a que s. exa. correspondeu, agradecendo e erguendo também vivas à república, ao sr. dr. Teófilo Braga e ao sr. governador civil»39. Mais tarde, acorreram também a saudar o novo secretário-geral as bandas «Emulação Popular», da Lagoa, e a «Rival das Musas», de Ponta Delgada.

O jornal $A$ Folha destacava também esta «calorosa manifestação» feita pela «classe popular» e salientava o espírito liberal de José Bruno:

«Além de homem de reconhecido talento, e por isso mesmo, o dr. José Bruno, como escritor, como jornalista, como tribuno, foi sempre rasgadamente liberal, terçando armas nunca embotadas contra a reacção, que durante tempos de ominosa memória, tudo parecia querer dominar e subverter» ${ }^{40}$.

36 Diário dos Açores, Ponta Delgada, 1910, Novembro, 18.

37 Como, aliás, o fazia notar, como exemplo de incoerência política, um jornal monárquico ribeiragrandense. A Semana, Ribeira Grande, 1910, Novembro, 5.

38 Diário dos Açores, Ponta Delgada, 1910, Novembro, 22.

39 Idem, Ponta Delgada, Novembro, 25.

40 A Folha, Ponta Delgada, 1910, Novembro, 27. 
Segundo Joaquim Manso, os amigos lisboetas de José Bruno, ao tomarem conhecimento do "seu triunfo burocrático choraram o seu óbito. Era homem ao mar...», terão dito ${ }^{41}$.

Esta nomeação não deixaria também de desencadear a forte crítica publicada no jornal de pendor monárquico $A$ Semana, da Ribeira Grande. No fundo, os monárquicos intransigentes acusavam-no de se ter tornado republicano para obter o lugar a que se candidataram vários interessados. Afirmava-se mesmo que o Governo tinha cometido uma ilegalidade, pois José Bruno não preencheria todas as condições exigidas, pelo Código Administrativo de 1878, para o desempenho do cargo, ao contrário do que acontecia com vários outros. Era, sem dúvida, uma maneira subtil de o acusar de adesivismo e de acusar o Governo de favoritismo numa nomeação que não devia ser considerada de confiança política ${ }^{42}$.

O Dr. João Bernardo Rodrigues levantava a hipótese de a fácil nomeação de José Bruno pelo novo regime se ter ficado a dever, quer "pela popularidade que o seu nome gozava desde os tempos universitários e ainda pela simpatia que merecera ao Partido Republicano com a sua violenta campanha contra a ditadura de João Franco». É uma hipótese bem de acordo com a realidade. Já atrás se citou o jornal $A$ Folha, em que era destacada a campanha de José Bruno contra o franquismo. Além disso, o próprio governador civil, Francisco Luís Tavares, tinha, de algum modo, uma dívida de gratidão para com José Bruno. De facto, quando, em Junho de 1907, um grupo de sete estudantes micaelenses da Universidade de Coimbra regressara à ilha, na sequência da greve académica e por não terem querido voltar às respectivas Faculdades enquanto não fossem reintegrados os alunos expulsos, o director do Distrito louvara-lhes a atitude, "pela altivez e nobreza» de que se revestira, honrando a palavra sem olhar aos interesses materiais em jogo ${ }^{43}$. Francisco Luís Tavares não se teria esquecido deste apoio do político regenerador e daí, talvez, não ter tido dúvidas em aceitar a sua nomeação, que, além do mais, podia ser vista como uma espécie de afirmação republicana de legalidade e tolerância.

Em 1918 o Dr. José Bruno Carreiro é nomeado chefe da Secção Civil do Gabinete do Alto-Comissário da República nos Açores, General Simas Machado. Com efeito, a entrada de Portugal na Grande Guerra e a instalação da Base Naval Americana nos Açores exigiriam uma «unidade de mando» que não se compadecia com a complexidade da organização administrativa dos Açores, divididos em três distritos, cada um com ligação directa ao governo central. É, também, o período sidonista das aspirações a uma «República Nova» que regenerasse a vida política nacional pelo império da ordem e da lei contra a demagogia. Mas este cesarismo populista de Sidónio Pais cairia, logo em Dezembro de 1918, com o seu assassinato.

41 Carta citada.

42 A Semana, Ribeira Grande, 1910, Dezembro, 10. A carta aberta de protesto foi, em primeiro lugar, entregue para ser publicada no jornal Correio Micaelense, que se mantinha hostil ao novo regime, que a recusou por se tratar de uma "questão de interesse pessoal do seu proprietário», o Dr. Humberto de Bettencourt de Medeiros e Câmara. Mesmo assim, o jornal não deixava de afirmar que se tratara de uma «flagrante injustiça perpetrada pelo ministro da república de nome António José de Almeida». Correio Micaelense, Ponta Delgada, 1910, Dezembro, 15.

43 O Distrito, Ponta Delgada, 1907, Junho, 27. 
José Bruno Carreiro mantinha-se, entretanto, ocupado no desempenho do seu cargo de confiança junto do alto-comissário. Não entrara na luta política aquando da constituição do Partido Regionalista entre 1917 e 1918. Seria isto inadequado, dadas as responsabilidades que assumira no gabinete do alto-comissário. E, além disso, as feridas que provocara enquanto director do jornal $O$ Distrito não estariam ainda, certamente, sanadas e José Maria Raposo de Amaral era o chefe incontestado dos regionlistas...

No fim da Guerra, José Bruno viaja com o almirante Dunn pela Europa, certamente como reconhecimento público do seu prestígio e do trabalho que desempenhara. E, segundo defendia o cônsul americano em Ponta Delgada, José Bruno seria «um dos principais animadores dos movimentos autonomistas dos Açores, [...] defendendo abertamente que se dev[ia] aproveitar o fim da Guerra para se conseguir uma maior autonomia», centrada no lema "os Açores para os Açorianos» 44.

José Bruno Carreiro intervinha, pois, ainda que não pudesse surgir a público. Mas o facto é que o Dr. João Bernardo Rodrigues levanta a hipótese de serem da sua autoria diversos artigos não assinados, publicados no Diário dos Açores em 1919, em que são dirigidas fortes críticas ao governo e reivindicado o alargamento da autonomia ${ }^{45}$.

Com efeito, o final da Guerra e a consequente extinção do cargo de alto-comissário iria marcar o início de um novo e importante debate sobre a autonomia dos Açores. Num desses artigos do Diário dos Açores, salientava-se que a intervenção dos Estados Unidos na Guerra viera trazer uma nova concepção da paz: um mundo novo, assente em «bases profundas de direito e de justiça», assegurando aos povos o "direito de disporem de si próprios, de se governar, de se administrar, de se desenvolver livremente, de dar livre expansão aos seus recursos e energias, sem peias sufocantes e sem entraves ao exercício das suas actividades» ${ }^{46}$. Neste sentido, integrando Portugal a Liga das Nações, logo, concordando com os princípios propostos pelo Presidente Wilson, seria justo que atendesse às aspirações de autonomia, numa perspectiva patriótica, acompanhando, aliás, o que se passava por toda a parte: o reconhecimento dos governos a um «mais largo exercício de direitos» dos povos sob sua jurisdição.

Fundamentada a autonomia nos princípios democráticos da participação das populações na condução dos seus próprios destinos e na descentralização como factor de reforço da coesão nacional, havia que investigar se os Açores apresentavam condições que justificassem a aplicação de um sistema administrativo autónomo. Um sistema verdadeiramente autónomo, e não a «burla» do decreto de 2 de Março de 1895, que se cifrara pela dependência constante das vicissitudes inerentes ao rotativismo monárquico. Neste sentido, a reclamada autonomia assentava em factos concretos - as "condiçōes especiais de vida", a "especial situação geográfica», o "próprio modo de ser» dos açorianos, que não se conformavam com o regime uniforme e centralizador do Estado português ${ }^{47}$. Assistência, saúde e higiene pública ${ }^{48}$, administração da

\footnotetext{
${ }^{4}$ António José Telo, Os Açores e o Controlo do Atlântico (1898/1948), Porto, Edições ASA, 1993, p. 155.

45 João Bernardo de Oliveira Rodrigues, ob. cit., p. 91.

46 Diário dos Açores, Ponta Delgada, 1919, Abril, 11.

47 Cf. Diário doa Açores, Ponta Delgada, 1919, Abril, 25.

48 Idem, Maio, 1.
} 
justiça ${ }^{49}$, instrução pública ${ }^{50}$ foram alguns dos temas focados nesse conjunto de artigos, certamente da pena de José Bruno, em que eram dirigidas fortes críticas à actuação do Estado relativamente aos interesses açorianos. A situação negativa que caracterizava os Açores era justificada, quer pela insuficiência dos investimentos públicos, quer pela ineficácia resultante das peias burocráticas que a centralização, que caracterizava a estruturação dos órgãos do Estado, impunha.

Em termos gerais, pretendia-se um sistema administrativo que permitisse a aplicação das receitas públicas geradas nos Açores em benefício das próprias ilhas, o aligeiramento dos entraves burocráticos, a diferenciação das leis a serem aplicadas nos Açores, o alargamento das competências (e consequentes responsabilidades) dos órgãos da administração açoriana.

A autonomia inseria-se, por outro lado, num esquema doutrinário que apelava à unidade e solidariedade açorianas e ao apartidarismo. Afirmava-se que a questão não era política, mas nacional, ou seja, referia-se ao conjunto de interesses e aspiraçôes das nove ilhas:

«A questão não é política. Para nós todos, açorianos, a questão é pura e simplesmente nacional, deixem-nos empregar esta expressão, tomando-a no sentido de com ela resumir o conjunto dos interesses e das aspiraçôes das nove ilhas dos Açores. Ao entrar nela todas as bandeiras partidárias devem ser abatidas, todas as divergências políticas devem ser tidas como não existentes. Nela não há, não pode nem deve haver distinção entre republicanos, monárquicos, socialistas» 51 .

A luta pela autonomia exigia, pois, que, como na campanha de finais do século anterior, se abatessem as bandeiras partidárias e se suspendessem as divergências políticas, nomeadamente quanto à questão do regime.

O discurso da unidade e da exaltação do serviço à causa superior do Arquipélago assumia evidentes intuitos mobilizadores da opinião pública açoriana, como o tinha também o recurso à propagação de uma imagem profundamente negativa do funcionamento dos serviços públicos nas ilhas. Assim, só após a conquista do sistema autonómico seria admissível, ainda que não desejável, o regresso às convicções políticas e à militância partidária. Até lá, a «unidade de pensamento e de acção» em torno do ideal autonomista seria incompatível com o desenvolvimento e afirmação de "personalismos» políticos, verdadeiro cancro que corroía a sociedade portuguesa ${ }^{52}$.

Estes artigos recuperam, sem dúvida, argumentos tradicionais do discurso descentralizador mas, por outro lado, o articulista adapta-os às novas realidades da política internacional. De facto, as constantes referências à projectada fundação da Sociedade das Nações e, fundamentalmente, à doutrina de Woodrow Wilson a propósito do direito à autodeterminação dos povos constituem elementos de destaque na fundamentação do direito dos açorianos a usufruírem de um sistema político-

49 Idem, Maio, 2.

50 Idem, Maio, 6.

51 Idem, Abril, 24.

52 Ibidem. 
-administrativo autónomo. Os exemplos citados das conversações entre os governos centrais e as regiōes que reclamavam a concretização das suas aspirações, a expressão nacional (ainda que em itálico) com referência ao tipo de mobilização que os açorianos teriam de encetar tendo em vista a concretização das suas aspiraçóes inserem-se num tipo de discurso que alguns sectores de opinião consideravam transportar uma certa ambiguidade. Assim, havia que recorrer constantemente à afirmação do acendrado patriotismo dos açorianos e do seu respeito pelas instituições do País 53 . Além disso, criticava-se fortemente os que viam no movimento intuitos separatistas:

«Não percamos tempo a falar na independência dos Açores e deixemos isso aos que, por motivos inconfessáveis, querem, na sombra e a ocultas, para hostilizar o movimento legal da autonomia, mostrá-lo como um movimento de ataque à integridade do Estado português. Os que assim procedem, ou o fazem por má-fé ou por uma deficiência intelectual que lhes não permite distinguir entre os objectivos e as finalidades de dois movimentos» 54 .

Estava, pois, traçado um novo capítulo na luta pela autonomia, agora procurando-se legitimá-la a partir das novas realidades, quer na política internacional, quer nas políticas internas dos Estados. Já então nos surgem os conceitos de "açorianismo", "consciência açoriana» e de "espírito açoriano" que, mais tarde, o Correio dos Açores iria aprofundar.

Esta nova campanha autonomista integraria, numa prática que, aliás, não era nova nos Açores ${ }^{55}$, excursões de dezenas de terceirenses a $S$. Miguel e de micaelenses à Terceira. O jornal Os Açores, de Angra do Heroísmo, apontava a importância destas visitas:

«Não resta dúvida nenhuma que estas visitas entre povos irmãos são como que enormes correntes eléctricas a estabelecer no espírito de todos nós uma precisa comunhão de ideias, uma forte unidade de pensamento, uma e outra muito úteis e indispensáveis sobretudo à nossa sagrada causa que defendemos com todo o ardor do nosso coração: - 'a Autonomia dos Açores' [...].

Basta dizer-se que a autonomia acabará por completo com os velhos processos de fazer política, 'cortará cerce o nó górdio' das dissençôes que tanto prejudicam a comunidade» 56

José Bruno Carreiro acompanhou também esta excursão, cabendo-lhe mesmo dirigir palavras de agradecimento ao empresário Alfredo de Mendonça, que proporcionara aos micaelenses uma visita à sua fábrica de lacticínios ${ }^{57}$.

53 Cf., por exemplo, Ibidem.

54 Ibidem.

55 V., a este propósito, Carlos Cordeiro, Nacionalismo, Regionalismo e Autoritarismo nos Açores durante a I República, Lisboa, Salamandra, 1999, pp. 270-277.

56 Transc. no Diário dos Açores, Ponta Delgada, 1919, Julho, 3.

57 Cf. Ibidem. 
Evidentemente que esta campanha também tinha os seus detractores. A imprensa da Horta ${ }^{58}$, por exemplo, mostrava-se profundamente contra a ideia e procurava sempre ligá-la às de independência e de separatismo, o que era, sem dúvida, agravado pelo facto de alguns jornais da comunidade açoriana nos Estados Unidos defenderem vigorosamente a independência dos Açores 59 . Tudo isto era repetidamente refutado pelos defensores deste novo movimento autonomista, que integrava credenciados republicanos como, por exemplo, Francisco d'Athayde Machado de Faria e Maia e o próprio Dr. Francisco Luís Tavares. Só assim, aliás, se compreenderá a sua adesão ao projecto do Correio dos Açores.

A 1 de Maio de 1920 sairia a público o primeiro número do Correio dos Açores, dirigido por José Bruno Carreiro e, durante curto espaço de tempo, Francisco Luís Tavares. Surgia numa conjuntura de crise económica e social, que caracterizou o imediato pós-I Guerra Mundial, no contexto de confronto ideológico e político que marcou a I República e numa conjuntura de forte debate autonomista. O editorial de apresentação destacava essa espécie de angústia que "as incertezas e dúvidas» do pós-guerra motivaram:

«É uma luz que está em marcha? Ou está-se a preparar inconscientemente o colapso geral da civilização com o regresso a um estado semi-bárbaro [...]? Caminha-se para um mundo melhor - ou está-se a cavar a ruína completa e a abrir a sepultura eterna de uma organização social que, se não era perfeita, dava ao menos aos homens uma ilusão de felicidade e, por vezes, uma ilusão de ideal realizado?» 60

Ora, estas preocupantes questôes que a direcção deixava expressas exigiriam o aprofundamento do debate e da reflexão sobre as novas realidades políticas, económicas e sociais que atravessavam todo o mundo, mas com uma atenção muito especial, como dizia ainda o editorial, ao «momento de crise» por que passava a vida açoriana. Havia, pois, que estudar as questôes de natureza económica, agrícola, industrial e comercial que pudessem interessar aos Açores.

58 Os jornais faialenses $O$ Telégrafo e $A$ Democracia enviam um telegrama às redacções dos jornais angrenses A Pátria, A União e O Democrata, nos seguintes termos: «Agradecemos saudação e olhos sempre fitos na Pátria portuguesa continuamos batalhando contra a autonomia dos Açores por grandemente prejudicial a todos os distritos, e ser sobretudo suspeitosa no actual momento". A Democracia, Horta, 1919, Julho, 25. Num outro artigo, A Democracia rejeita novamente a possibilidade de uma autonomia para os Açores, aceitando somente a possibilidade de uma autonomia para o distrito, «feita em moldes muito nossos - dizia o articulista - e com uma orientação inteiramente diversa da que acarretou os graves desastres financeiros de Ponta Delgada e Angra». Mas, mesmo assim, considerava que havia que esperar pela melhoria do ambiente político, quando se esquecesse a campanha separatista de jornais portugueses dos Estados Unidos. Este artigo surgiu na sequência de uma projectada deslocação à Horta de uma comissão autonomista de Angra do Heroísmo, a fim de servir de mediadora na questão entre as elites políticas faialenses e as micaelenses. A Democracia, Horta, 1919, Julho, 9. Num outro número do jornal afirmava-se: «não existe entre os Açores e a Metrópole nenhuma questão diferente que justifique o movimento autonómico em projecto». A Democracia, Horta, 1919, Julho, 3.

59 Um artigo do jornal O Popular, de New Bedford, teve grande repercussão, precisamente por defender a autonomia dos Açores, tendo sido transcrito em diversos jornais dos Açores e de Lisboa. Cf., Diário dos Açores, Ponta Delgada, 1919, Setembro, 17.

60 Correio dos Açores, Ponta Delgada, 1920, Maio, 1. 
Nos anos '20, o Correio dos Açores, sob a direcção de José Bruno Carreiro, seria essencial para conferir uma nova dinâmica, um novo percurso e, sobretudo, nova perspectiva de enfoque da questão autonomista. Um debate amplo e, digamos, pluridisciplinar, que concitou à sua volta intelectuais, políticos, empresários, jornalistas, profissionais liberais, com visões diferentes, é certo, sobre a problemática autonómica, mas tentando contribuir para justificar e legitimar o estatuto de «maioridade do povo açoriano" e a sua capacidade de auto-administração.

Para começar, uma espécie de "inquérito" à situação dos Açores — o "problema açoriano». Procurava mobilizar-se a sociedade para uma reflexão sobre a realidade açoriana, as suas potencialidades e os seus constrangimentos, numa época de profunda crise que os efeitos da guerra agravaram. Não se tratava de visar exclusivamente a problemática administrativa, mas de alargar os horizontes da discussão à economia, às finanças, à cultura e à identidade. Pode, talvez, dizer-se que o período de 1919-20 a 1926 é o que revela o discurso autonomista mais profundo e abrangente, e em que o jornal Correio dos Açores desempenhou papel de liderança.

Com efeito, e pela mão de José Bruno Carreiro, de quem era amigo, o terceirense Luís da Silva Ribeiro, republicano e democrata, teria um papel de destaque na defesa da cultura açoriana e da necessidade de preservação dos traços culturais da vivência insular. No fundo, com o contributo dele e de diversos outros colaboradores, procurava chamar-se a atenção para a identidade açoriana, ainda que inserida num contexto mais vasto da «raça». O povo açoriano seria lídimo representante da raça, até por preservar muitas das características do povo português dos tempos áureos dos Descobrimentos que se haviam perdido no continente. A história e a geografia teriam feito o resto. Não se tratava, acentuava-se, de uma cultura uniforme em todas as ilhas, mas com traços comuns que havia que divulgar para que os açorianos se convencessem de que pertenciam a uma realidade que ultrapassava a da sua ilha ${ }^{61}$.

Um outro aspecto em que José Bruno e os colaboradores do Correio dos Açores apostaram firmemente foi no da necessidade de "construção" da unidade açoriana. Seria uma preocupação constante, que perpassa inúmeras páginas do jornal. Para tanto era necessário que os açorianos se conhecessem mutuamente, para o que contribuiriam eficazmente as viagens de confraternização inter-ilhas, o intercâmbio cultural, os torneios desportivos, etc. Através do convívio e do conhecimento mútuo seria possível alcançar-se a confraternidade açoriana que se almejava. Luís Ribeiro, por exemplo, acreditava que a questão administrativa devia ser o corolário da conjugação de interesses económicos entre as diversas ilhas e de uma «consciente solidariedade moral», ou seja, do espírito açoriano, em contraponto aos egoísmos e mesmo aos ódios insulares. No fundo, à identificação com a ilha procurava substituir-se a identificação com o arquipélago, fundamentada na "comunhão de interesses», na «semelhança de temperamentos», na "unidade física», de modo a surgir uma verdadeira consciência açoriana ${ }^{62}$. Espírito açoriano, sentimento açoriano, açorianismo, consciência açoriana integrariam, pois, a nova perspectiva com que a problemática autonomista passaria a ser tratada.

\footnotetext{
${ }^{61}$ Cf. Carlos Cordeiro, ob. cit., capítulo III.

${ }^{62}$ Cf. Ibidem.
} 
Em 1921, o Correio dos Açores esteve na linha da frente de apoio às candidaturas regionalistas para as eleições legislativas desse ano. No editorial intitulado «Nós, os açorianos», certamente da autoria de José Bruno, destacava-se precisamente a necessidade de, acima dos interesses político-partidários, se praticar a "política de interesses açorianos», já que os açorianos viviam longe das lutas e paixões que caracterizavam a vida política nacional: "Lisboa dá o mot d'ordre e toda a carneirada da província obedece servilmente». Assim, havia que ter o maior cuidado na escolha dos candidatos de modo ficarem bem colocados junto do poder. A «questão exclusivamente política» (entenda-se, a questão do regime) devia ser afastada da campanha e daí a crítica ao facto de ter sido escolhido como candidato a deputado o monárquico assumido, que participara na revolta de Monsanto ao lado dos monárquicos, António Hintze Ribeiro ${ }^{63}$. O que é certo é que os regionalistas ganharam as minorias e os liberais as maiorias ${ }^{64}$.

Estes resultados positivos dos regionalistas e a campanha que o Correio dos Açores vinha liderando na imprensa regional na divulgação dos ideais autonomistas e na afirmação da identidade açoriana desencadearam uma campanha violentíssima contra José Bruno Carreiro, vinda especialmente da parte de jornais do Continente conotados com os sectores mais radicais do PRP. Além das recorrentes acusaçôes de "monarquismo», mais graves eram as expressas imputações de separatismo aos desígnios do movimento autonomista. O jornal A Imprensa da Noite seria o principal porta-voz desse tipo de ataques, levantando inclusivamente suspeitas sobre o papel de José Bruno em imaginadas conversações para a passagem dos Açores para a soberania dos Estados Unidos da América, ligando-as à viagem que fizera acompanhando o Almirante Dunn e a documentação existente no Ministério dos Negócios Estrangeiros ${ }^{65}$.

$\mathrm{Na}$ sessão do Senado, de 5 de Agosto de 1921, o senador pelo círculo de Ponta Delgada António Alves de Oliveira Júnior faz uma intervenção para rebater ponto por ponto as afirmações "torpes» de certa imprensa lisboeta a respeito do movimento autonomista açoriano e, sobretudo, sobre as intenções de José Bruno Carreiro, que afirmava ser um "espírito lucidíssimo, avançado», com "altas qualidades de inteligência e cultura", que prestara "grandes serviços» ao regime. E sobre as movimentações autonomistas defendia:

«Todos sabem que da união de todos os açorianos mais força lhes pode advir e desta maneira tem-se procurado estabelecer entendimentos entre os dois distritos açorianos que já hoje pela legislação do nosso País têm uma certa descentralização administrativa que lhes foi conferida em 1895 e que de então para cá, triste é dizê-lo, só tem sido cerceada.

O que é legítimo, pois, é que essa descentralização seja alargada.

Não há portanto no pensamento ou sentimento de qualquer açoriano a ideia de se separar dos destinos da sua Pátria» 66.

63 Cf. Correio dos Açores, Ponta Delgada, 1921, Junho, 18.

${ }^{64}$ Cf. Idem, Ponta Delgada, 1921, Julho, 12.

65 Infelizmente, não pudemos consultar directamente os artigos do jornal, mas as intervenções no Senado em defesa de José Bruno apontam precisamente nesse sentido.

66 Cf. Diário do Senado, sessão n. ${ }^{4}$ 4, de 5 de Agosto de 1921, p. 14. 
Simas Machado, que fora, como se referiu, alto-comissário da República nos Açores, verberando também as interpretaçóes da existência de um movimento separatista nos Açores, afirmava, sobre a personalidade de José Bruno Carreiro:

«Esse cavalheiro comportou-se para comigo com a maior lealdade, como homem de muita inteligência e vasta ilustração, nunca me dando a menor manifestação de ideias separatistas, pelo contrário, advogando sempre uma ampla autonomia em favor do arquipélago» 67 .

A posição de José Bruno Carreiro foi a de não conferir qualquer relevo público às acusações. Conforme revela numa carta de agradecimento enviada a Simas Machado, nem o seu jornal ${ }^{68}$ nem qualquer dos Açores fizeram transcrições de tão graves suspeitas lançadas sobre si e, em termos gerais, sobre o movimento autonomista. Nessa carta $^{69}$, José Bruno agradece o apoio que Simas Machado lhe manifestara no Senado e apodava o autor dos artigos de "garotóide e escroque» que pretendia da chantagem fazer modo de vida ${ }^{70}$.

Esta caminhada para a tentativa de alargamento das prerrogativas autonomistas integraria um novo episódio, sem dúvida, concebido por José Bruno Carreiro: o famoso editorial de Agosto de 1922 - se a Madeira quisesse - que, no fundo, procurava conciliar esforços dos distritos autónomos para a luta comum em torno do ideal emancipador, uma vez que jornais da Madeira já pugnavam pela «completa e absoluta autonomia», "devendo a bandeira ser a única ligação com a mãe-pátria» 71 . O tipo de discurso autonomista de José Bruno parece tornar-se mais radical: os Açores e a Madeira viviam no mesmo regime "de espoliação, em benefício dos interesses das clientelas» com sede em Lisboa, que só pensavam nas ilhas para as «ordenhar, como a bujodíssimas tetas de rebanhos dóceis à voz e à vara do pastor» ${ }^{72}$. Além disso, também aos dois arquipélagos aplicava o tradicional argumento de as populaçôes

\footnotetext{
67 Ibidem, p. 16.
}

68 «Nem sequer me refiro aos artigos (?) da Imprensa da Manhã. Qualquer referência poderia levar-me longe, com o inconveniente de poder dar a entender que sinto necessidade de me defender». "Carta de José Bruno Carreiro a Simas Machado», Ponta Delgada, 1921, Agosto, 28. Arquivo Simas Machado, pertença da Dra Eugénia Paím Xavier (bisneta do General Simas Machado).

${ }^{69}$ Uma palavra de profundo reconhecimento dirijo ao Senhor Eng. ${ }^{o}$ Luís Bonifácio, responsável pelo blogue "Cartas Portuguesas», que me cedeu três cartas dirigidas por José Bruno Carreiro a Simas Machado. Ao consultar o blogue, verifiquei que lá estavam publicadas cartas dirigidas a Simas Machado. Ainda que não tivesse qualquer esperança de ser atendido, dirigi um e-mail ao endereço que lá vinha indicado, perguntando se havia correspondência dirigida por José Bruno a Simas Machado. Rapidamente recebi resposta afirmativa, com o resumo das cartas existentes e a abertura à possibilidade de digitalização das que eu considerasse mais importantes. Foi precisamente isto que veio a acontecer. A presteza e simpatia do Senhor Eng. ${ }^{\circ}$ Luís Bonifácio merecem, pois, o meu agradecimento.

70 «Carta...» citada.

71 Cf. Nelson Veríssimo, O Alargamento da Autonomia dos Distritos Insulares. O Debate na Madeira (1922-1923), sep. das "Actas do II Colóquio Internacional de História da Madeira», Funchal, Região Autónoma da Madeira/Secretaria Regional do Turismo, Cultura e Educação/Centro de Estudos de História do Atlântico, 1989, pp. 493-494.

72 «Se a Madeira Quisesse...», in Correio dos Açores, Ponta Delgada, 1922, Agosto, 15. 
respectivas não terem sido responsáveis pela situação política, económica, financeira e social que se traduzia por uma profunda decadência e uma aproximação progressiva e inexorável do precipício. Antes, as populaçōes dos Açores e da Madeira seriam modelos de ordem e de trabalho.

Assim, com fundamentação idêntica e os mesmos motivos de queixa, nada obstava à definição de uma estratégia reivindicativa comum, visando a conquista das faculdades de uma "autêntica» e "verdadeira» administração autónoma que permitisse aos distritos insulanos alcançarem a realização das suas aspirações. Com a união de açorianos e madeirenses mais viável seria a compreensão e atendimento das reclamaçôes dos dois arquipélagos que apelavam por justiça, por considerarem que o produto do seu trabalho revertia frequentemente para obras de que não recebiam qualquer benefício, uma vez que estavam implantadas no continente:

«Tudo isso pagámos, estamos pagando e continuaremos a pagar, englobados, como carneiros, nas sangrias do fisco, com a riqueza das nossas exportações sujeita a quantas sobretaxas se lembrem de lhes impor, continuando privados de tudo aquilo de que mais precisamos, reduzidos à miséria vergonhosa de ter de pedir, como se pede uma esmola, essa coisa na verdade formidável - um subsídio para um hospital»73.

Encontramo-nos, pois, perante um discurso de tipo catastrofista que, não apelando à revolta das populações, procurava, todavia, nelas incutir o sentimento da justiça dos protestos insulares contra o abandono a que as ilhas eram votadas pelo governo central. Simultaneamente, procurava firmar-se a base social de apoio à estratégia de aliança com a Madeira no processo reivindicativo autonomista. Com efeito, a conquista do regime descentralizador só seria possível alcançar pela via institucional - pelo trabalho empenhado dos deputados e senadores —, mas isto exigia largo apoio da população, que era preciso, portanto, mobilizar para a causa.

Este importante editorial de José Bruno Carreiro, pelas repercussões que gerou e pela adesão da imprensa madeirense ao projecto, desencadearia uma transformação essencial no debate autonomista: de jornalística, a questão passaria a institucional, com a intervenção da Junta Geral do Distrito do Funchal a propor a conjugação de iniciativas dos três distritos autónomos - Ponta Delgada, Angra do Heroísmo e Funchal - em prol da autonomia, apelando-se à união de açorianos e madeirenses, no sentido de, no parlamento, se verificar a cooperação dos representantes das ilhas na defesa do ideal comum ${ }^{74}$. A Junta Geral de Ponta Delgada também decidiu dar o seu apoio ao projecto de união entre a Madeira e os Açores, tendo convocado uma assembleia com representação de todas as classes e opiniōes do distrito, a fim de se decidir sobre o melhor modo de apoiar a iniciativa da Junta Geral do Funchal, que fora, provavelmente, despoletada pelo editorial de José Bruno ${ }^{75}$. Nos finais de 1922 e inícios de 1923 deslocam-se à Madeira José Bruno Carreiro, Luís de Bettencourt e, como representante do distrito de Angra do Heroísmo, Luís da Silva Ribeiro ${ }^{76}$.

\footnotetext{
73 Ibidem.

74 Cf., Nelson Veríssimo, ob. cit., p. 497.

75 Cf. A Actualidade, Ponta Delgada, 1923, Janeiro, 6.

76 Cf. Nelson Veríssimo, ob. cit., p. 502.
} 
No regresso à ilha, os dois representantes de $S$. Miguel foram recebidos em apoteose e num comício muito participado apresentaram à população os resultados dos seus contactos na Madeira. Pretendia-se, no fundo, manter viva a campanha autonomista e conquistar para a causa o maior número possível de cidadãos, de modo a conferir-lhe uma firme base social de apoio ${ }^{77}$.

Não teve sequência esta aproximação dos distritos autónomos insulares. A pretensão de alargamento da autonomia, que mobilizava vontades nos dois arquipélagos, não significava identidade de pontos de vista quanto aos projectos concretos a apresentar. As realidades de cada um dos distritos eram diferentes e a tradição do empenhamento em defesa da descentralização, também. Não seria curial impor uniformidade estatutária aos três distritos, quando se reclamava a autonomia precisamente a partir do pressuposto de que realidades diferentes exigiam leis diferentes.

Nesta conjuntura de efervescência autonomista, em que se destacavam, incontestavelmente, o Correio dos Açores e o seu director José Bruno, e que congregara em seu torno boa parte das elites açorianas, há também a destacar a «visita dos intelectuais», em 1924.

Com efeito, um dos aspectos fundamentais com que se tinham de debater os regionalistas e autonomistas açorianos relacionava-se com a imagem que as reivindicações descentralizadoras colhiam nos círculos políticos e jornalísticos continentais. As posições em prol da descentralização açoriana eram, amiúde, confrontadas com críticas acesas e com desconfianças sobre os verdadeiros intuitos políticos dos respectivos defensores. José Bruno Carreiro verificara, pois, a necessidade de associar à introspecção, que o projectado, mas só concretizado em 1938, congresso açoriano seria vertente fundamental, a projecção para o exterior da realidade açoriana, nas suas múltiplas facetas — e não só na politico-administrativa. Seria, pois, essencial que os protestos e as propostas açorianas encontrassem no continente, se não apoio, ao menos um ambiente não hostil. José Bruno Carreiro considerava, assim, que a "propaganda dos Açores» no continente constituía um aspecto fundamental da campanha regionalista. A actividade dos açorianos residentes em Lisboa seria, na sua perspectiva, insuficiente para que a campanha atingisse os fins almejados. A solução teria de ser a inversa: conseguir que fossem os próprios continentais a falar das ilhas. Havia que trazer aos Açores continentais que, "pela sua cultura, pela sua ilustração, pela sua posição nos meios intelectuais e no meio social português», assumissem, no seu regresso ao continente, o papel de uma espécie de embaixadores dos Açores junto da opinião pública nacional ${ }^{78}$.

A visita seria suportada financeiramente pelo contributo de diversas firmas locais e pela colaboração de particulares. A «missão intelectual» incluía Antero de Figueiredo, José Leite de Vasconcelos, Teixeira Lopes, Luís de Magalhães, Henrique Trindade Coelho, Joaquim Manso, Armindo Monteiro, D. Luís de Castro e D. Manuel Ribeiro de Bragança. Acompanhavam a Missão os jornalistas Armando Boaventura, Oldemiro César e Raposo de Oliveira. A recepção por parte dos convidados foi, em alguns casos, entusiástica $^{79}$.

\footnotetext{
77 Correio dos Açores, Ponta Delgada, 1923, Janeiro, 23.

78 Correio dos Açores, Ponta Delgada, 1924, Março, 23.

${ }^{79}$ V., por exemplo, as cartas de Luís de Magalhães e de José Leite de Vasconcelos. SDUA, Fundo Carreiro da Costa.
} 
Nas suas intervenções públicas, José Bruno Carreiro não procurava iludir os objectivos autonomistas que haviam presidido à concretização da «missão intelectual». O contraste, sempre acentuado, entre um povo trabalhador e sério e o abandono a que era votado pelos poderes centrais justificaria o aprofundamento das prerrogativas descentralizadoras conferidas pelo decreto de 2 de Março de 1895. Os açorianos pretenderiam somente usufruir da liberdade para trabalhar, progredir, ter «voz no governo da sua casa», na convicção de que, pelo conhecimento directo da realidade e pela capacidade e competência demonstradas, ninguém melhor do que os insulares poderiam administrar os seus próprios interesses. Era, portanto, esta «mensagem» que o director do Correio dos Açores pretendia que os visitantes fizessem passar para a opinião pública nacional:

«Eu mentiria a Vossas Excelências se lhes não dissesse aqui que foi em grande parte o pensamento egoísta de conquistarmos novos e poderosos advogados para as nossas reivindicações que inspirou a viagem que trouxe Vossas Excelências aos Açores [...]. Agora que tudo lhes mostrámos e tudo lhes dissemos, só nos resta pedir-lhes que, ao fim de tantas canseiras e fadigas que lhes impusemos, de tanto abuso da sua paciência e amabilidade, nos manifestem, nos grandes meios a que em breve regressarão, um pouco da sua solidariedade, que será para os açorianos um alto e poderoso conforto moral, na amarga desolação do abandono a que tantas vezes nos sentimos votados» 80 .

Além de dois livros publicados, na sequência da viagem, por dois dos visitantes, a «Missão Intelectual» contribuiu, sem dúvida, para a divulgação, na imprensa continental, de uma imagem positiva dos Açores e do seu povo e também para a propagação, a nível nacional, das teses autonomistas açorianas. Internamente, a jornada serviu como elemento mobilizador em torno da autonomia e de acentuação do prestígio do "grupo do Correio dos Açores» e do seu líder, José Bruno Carreiro.

As movimentações em torno da visita levariam o governador civil substituto de Ponta Delgada a produzir um relatório, criticando acerbamente o comportamento de diversos funcionários públicos, acusando-os de manifestaçōes monárquicas. Como resultado, houve a transferência de dois funcionários para o continente e a suspensão de Aristides Moreira da Mota do seu lugar de professor do Liceu de Ponta Delgada. $\mathrm{O}$ assunto foi debatido em ambas as câmaras do parlamento, na imprensa de Lisboa e na dos Açores. Fora, no fundo, uma grande vitória para a causa autonomista, pela onda de solidariedade que estas medidas punitivas governamentais geraram em torno dos visados e, especialmente, de Aristides da Mota ${ }^{81}$.

No fundo, o relatório do governador civil substituto, Jaime Hintze - que fora militante monárquico e que era acusado, por isso mesmo, de pretender afirmar créditos

80 Correio dos Açores, Ponta Delgada, 1924, Junho, 14.

81 O republicano «histórico» Henrique Brás dava bem conta disso mesmo, numa carta dirigida a José Bruno: «Felicito vivamente o meu excelente Amigo pelo êxito, superior a toda a expectativa, da visita dos intelectuais, êxito que a perseguição idiota ao dr. Aristides Moreira da Motta veio tornar ainda mais retumbante». Correio dos Açores, Ponta Delgada, 1924, Julho, 13. 
de «bom republicano» - e as precipitadas decisões disciplinares dos ministros da Agricultura e da Educação serviram, fundamentalmente, os interesses dos regionalistas micaelenses. Com efeito, a fortíssima campanha que o Correio dos Açores lidera na condenação das medidas governamentais relativamente àqueles funcionários públicos e os apoios que o jornal foi recebendo de personalidades de diversos quadrantes políticos, quer dos Açores quer do Continente, contribuiriam para reforçar as críticas ao poder central e apelar ao reforço da unidade em torno dos ideais autonomistas. Por outro lado, os parlamentares monárquicos souberam bem aproveitar-se da situação para, em ambas as câmaras, dirigirem fortes ataques à situação política vigente, acusando os republicanos de intolerância política e de perseguições sistemáticas aos seus opositores políticos.

No rescaldo dos acontecimentos, em carta ao General Simas Machado, José Bruno Carreiro é extremamente crítico quanto ao comportamento de alguns políticos do partido democrático:

«Publiquei há pouco no Correio a sua bela carta ao dr. Aristides, protestando contra o vexame e a violência de que foi vítima por parte destes ascorosos políticos, em que se não sabe o que mais admirar: se a imbecilidade, se a maldade, se a desfaçatez, se o cinismo. [...] O que 3 ou 4 (não mais) democráticos urdiram e conchavaram em volta da visita da missão de continentais, com uma teia de mentiras e calúnias, é simplesmente fantástico. [...] O que é assombroso é que, apesar de o resto do partido, com os principais magnatas à frente, tomar posição, publicamente, contra o que fez o governador civil substituto [...], houve ministros que lhe deram ouvidos, praticando e fazendo a sementeira de ódios e dissençôes que para aí foi lançada. Que miséria!»82.

Em 1925, já com sinais bem significativos do fim da I República, o Correio dos Açores, empenhava-se novamente na luta política: era necessário encontrar consensos em torno da ideia descentralizadora e da possibilidade de os parlamentares dos quatro distritos insulares (Madeira e Açores) definirem uma plataforma comum de actuação nas respectivas câmaras.

A análise «dramática» da situação política nacional, baseada num «modelo» definido pela oposição entre as qualidades do povo e a corrupção dos políticos, os altos interesses nacionais e a defesa egoísta dos interesses individuais ou de facção, as virtudes da unidade face à decadência provocada pela "pulverização" partidária iria desencadear, no distrito de Ponta Delgada, um movimento tendente à constituição da «unidade conservadora". A unidade de acção conservadora encontrara em Filomeno da Câmara o verdadeiro símbolo do combate patriótico contra os "desmandos» da vida política portuguesa. Solicitava-se, pois, a aceitação da sua candidatura a deputado regionalista, pelo círculo de Ponta Delgada, juntamente com a de Herculano Amorim Ferreira, engenheiro militar, também natural da Ilha de S. Miguel ${ }^{83}$. O lema da campanha lançado por Filomeno da Câmara seria «a revolta dos escravos». José Bruno Carreiro,

82 "Carta de José Bruno Carreiro a Simas Machado», Ponta Delgada, 1924, Agosto, 24. Arquivo Simas Machado, pertença da Dra Eugénia Paím Xavier.

83 Cf. Luís Menezes, As Eleições Legislativas de 1921 e 1925 no Arquipélago dos Açores, s/l [Angra do Heroísmo], SREC/DRAC, s/d [1992], pp. 158-159. 
ainda que tenha recusado imediatamente o convite para se candidatar a deputado 84 , envolveu-se directamente na campanha eleitoral ${ }^{85}$. Os resultados foram óptimos para os regionalistas: venceram as eleiçôes, elegendo Filomeno da Câmara e Herculano Amorim Ferreira como deputados. Em 1927, José Bruno Carreiro diria mesmo que esta vitória regionalista podia ser designada como o "28 de Maio dos micaelenses».

De facto, como aconteceria com a maioria da população portuguesa, o " 28 de Maio" foi recebido, nos Açores, com uma atitude de expectativa benevolente. Pelo Decreto 14 402, de 7 de Outubro de 1927, seria criado o cargo de Delegado Especial do Governo da República nos Açores, com funções de superintendência nos serviços da administração pública e com competências de nomeação e demissão de autoridades administrativas e militares. Além do mais, teria especiais responsabilidades no controle dos deportados políticos que se encontravam dispersos por diversas ilhas dos Açores, mas, sobretudo, na Terceira. José Bruno Carreiro foi logo nomeado chefe de gabinete da secção civil, colaborando, assim, directamente com o detentor do cargo, coronel Silva Leal, enquanto este mantivesse a sede em Ponta Delgada ${ }^{86}$.

Após a instauração da Ditadura Militar, José Bruno esperava, numa atitude por ele mesmo caracterizada de «reservada», a reforma administrativa, pois as circunstâncias políticas aconselhavam o «abandono dos programas de vastas reivindicaçôes» apresentados em diversas conjunturas. A justificação de José Bruno para esta tomada de posição sobre a autonomia seria aprofundada numa conferência realizada no Grémio dos Açores, em Lisboa. De uma visão optimista sobre a capacidade dos açorianos para gerirem, competente e honestamente, os seus próprios recursos, passara a uma perspectivação céptica sobre as relações sociais e os interesses económicos e políticos que, sobretudo após a Guerra, haviam abalado os "fundamentos das velhas sociedades» e a que a população açoriana não teria ficado imune. As «fissuras» eram já notórias na «estrutura do velho templo» da sociedade açoriana; por toda a parte surgia uma verdadeira "onda de apetites». Além disso, nos distritos açorianos e mesmo no de Ponta Delgada verificavam-se já défices nas contas públicas ${ }^{87}$.

José Bruno Carreiro não tem dúvidas: perante a situação dos distritos e o contexto político nacional, havia que enveredar pelo pragmatismo. Abandonava-se a discussão sobre a divisão administrativa dos Açores, geradora sempre de grandes polémicas; não se debatiam as questôes ligadas ao modelo de representação política nas instituições autonómicas; abandonava-se a defesa do alargamento das competências das juntas gerais. Preconizava-se, somente, manter a configuração administrativa descentralizadora de 1895 e o alargamento da autonomia financeira distrital. Seria esse o fio condutor que iria imperar durante os dois primeiros anos da vigência da Ditadura Militar.

${ }^{84}$ Correio dos Açores, Ponta Delgada, 1925, Setembro, 18.

85 Idem, Ponta Delgada, 1925, Outubro, 18.

${ }^{86}$ Sobre o cargo de cargo de Delegado Especial do Governo da República nos Açores e o papel de Silva Leal veja-se, por exemplo, José Olívio Mendes Rocha, Autoritarismo e Resistência nos Açores. O papel do Delegado Especial do Governo da República nos Açores - 1927-1931, Ponta Delgada, Universidade dos Açores, 2005 (dissertação de Mestrado, policopiada).

87 Cf. Correio dos Açores, Ponta Delgada, 1928, Fevereiro, 1. 
E é este tipo de intervenção mais pragmática e, digamos, economicista que iria ter sucesso, pois alcançara também o apoio do Delegado Especial do Governo da República nos Açores, coronel Silva Leal. Negociado o novo diploma legal em Lisboa, com a participação activa de José Bruno e de Silva Leal, o resultado foi a passagem de receitas de diversos impostos para as juntas gerais e de algumas despesas para o governo. Ou seja, garantia-se um maior desafogo financeiro às administraçóes distritais, que era, no fundo, o que se pretendia ${ }^{88}$.

Houve, naturalmente, grandes manifestações populares em torno de José Bruno e do Coronel Silva Leal.

Poucos meses passados, a euforia daria lugar ao desalento. Na sua política de controlo e contenção financeiros, objectivando o equilíbrio do orçamento de Estado, Salazar iria alterar profundamente, pelo decreto de 31 de Julho de $1928^{89}$, o de 16 de Fevereiro do mesmo ano que tanto apoio tinha recebido em S. Miguel. Alegando o reconhecimento da capacidade de os distritos autónomos se administrarem com eficácia, e, portanto, com mais autonomia, Salazar sufocaria financeiramente as juntas gerais, retirando-lhes receitas e acrescendo-lhes encargos. Nessa conjuntura, José Bruno Carreiro não deixou de protestar, a despeito das críticas que lhe eram dirigidas pelos indefectíveis da Ditadura Militar. Num importante editorial do Correio dos Açores, em que é fortemente criticada a política de "facto consumado», como tinha sido a publicação do decreto de Salazar, o seu director afirma: «Por um critério que talvez possa ser arguido de excessivamente materialista, avaliamos um regímen de administração pública pela forma como serve os interesses dessa administração e não pelas palavras em que é formulado. Não é por sport que se têm travado as várias campanhas autonomistas. Ninguém as travou para experimentar nos Açores teorias de descentralização administrativa. Foram travadas com uma visão objectiva de realidades e interesses» ${ }^{90}$. E esta perspectiva negativa seria retomada em 1934, ou seja, seis anos após a entrada em vigor do novo decreto, numa carta aberta ao ministro do Comércio, que então visitava os Açores. Segundo José Bruno Carreiro, era aflitiva a situação financeira da Junta Geral de Ponta Delgada, na medida em que cerca de 68\% das receitas eram aplicados nos serviços de obras públicas e instrução, ficando os restantes serviços com escassas verbas para atingir os objectivos que se lhes impunham ${ }^{91}$.

A finalizar, recuperemos a sua importante conferência Autonomia Administrativa dos distritos das ilhas adjacentes, publicada pelo Instituto Cultural de Ponta Delgada e recentemente reeditada. Trata-se de um texto fundamental e de leitura, digamos, obrigatória para quem se interessa pelas questôes autonomistas, e não só os historiadores ou homens de cultura.

\footnotetext{
${ }^{88}$ Decreto de 16 de Fevereiro de 1928, de mais fácil consulta em José Guilherme Reis Leite (organização, prefácio e notas), A Autonomia dos Açores na Legislação Portuguesa. 1892-1947, Horta, Assembleia Regional dos Açores, 1987, pp. 207-218.

89 Cf. idem, pp. 220-225.

90 Correio dos Açores, Ponta Delgada, 1928, Agosto, 3.

91 Cit. em José Bruno Carreiro, A Autonomia Administrativa dos Distritos das Ilhas Adjacentes, Ponta Delgada, Jornal de Cultura, 1994, p. 71. (1. a edição, sep. de «Insulana», vol. 8, n. ${ }^{\text {os }} 1 / 2$ (1952), Ponta Delgada, Instituto Cultural de Ponta Delgada.
} 
Desde logo, uma perspectiva da autonomia, não como resultante de conjunturas económicas, sociais ou políticas específicas, mas de um longo processo histórico marcado pela insularidade, que criara um modo de ser específico do povo dos Açores, uma, como disse, "personalidade diferenciada da população continental». Fora esta personalidade, ou identidade, marcada pela história e pela geografia, a insularidade, que justificara, por exemplo, o movimento autonomista de 1895 .

Depois de uma passagem pelos principais factos históricos em que os Açores tiveram papel relevante na história de Portugal e internacional e de salientar a importância geoestratégica das ilhas, José Bruno Carreiro apresenta cruamente a situação de crise económica e social que grassava no distrito de Ponta Delgada, sem que a Junta Geral tivesse qualquer capacidade para lhe acorrer, pela escassez de recursos financeiros. Críticas fortes, sem dúvida, mas dirigidas em tom cordato.

Mas, mesmo com estas críticas ao funcionamento das juntas gerais autónomas, por falta de verbas para o investimento, José Bruno mantém-se firme na defesa da autonomia, contrariamente a algumas vozes que, desde há mais de uma década já se manifestavam no sentido de não se justificar a autonomia, pois o governo do Estado Novo tudo resolveria a bem dos açorianos. José Bruno acreditava, pelo contrário, nas capacidades das corporaçôes locais para decidirem o melhor para o desenvolvimento do distrito, sem as peias do Terreiro do Paço e os constantes beija-mãos a funcionários das repartiçôes centrais. O problema não era o de alargar a autonomia administrativa, mas sim a financeira.

José Bruno Carreiro manteve-se, pois, fiel ao ideal da «livre administração dos Açores pelos açorianos». Por ele se bateu em diversas frentes e sob várias perspectivas. Uma autonomia fundamentada na identidade do povo açoriano e legitimada pelo seu sentido nacional e patriótico. 

Série

Documentos

Imprensa da Universidade de Coimbra

Coimbra University Press

2010

- U

C • 